\title{
STIFLING OF CREVICE CORROSION IN ALLOY 22
}

\author{
Kevin G. Mon', Gerald M. Gordon' and Raúl B. Rebak ${ }^{2}$ \\ 'Framatome ANP; 3315 Old Forest Road; Lynchburg, VA 24501 \\ ${ }^{2}$ Lawrence Livermore National Laboratory, 7000 East Ave, L-631, Livermore, CA 94550
}

Keywords: N06022, Constant Potential, Crevice Corrosion, Stifling, Chloride, Nitrate

\begin{abstract}
Artificially creviced Alloy 22 (N06022) specimens may be susceptible to crevice corrosion in presence of hot chloride containing solutions. The presence of oxyanions in the electrolyte, especially nitrate, may inhibit the nucleation and growth of crevice corrosion. Constant potential tests were performed using tightly creviced specimens of Alloy 22. It was found that crevice corrosion may initiate when a constant potential above the crevice repassivation potential is applied. It was found that as the crevice corrosion nucleated, the current initially increased but later decreased. The net measured current can be converted into penetration following a power law fit of the experimental data. The average power law coefficient " $n$ " was found to be 0.439 , suggesting that even under constant applied potential, crevice corrosion penetration is diffusion controlled.
\end{abstract}

\section{Introduction}

Alloy 22 was selected as the outer shell material of the high level nuclear waste containers for the Yucca Mountain repository $[1,2]$. Aqueous salt solution may enter in contact with the containers during their emplacement time. These solutions are predicted to be concentrated and contain, among other species, chloride and nitrate. The solutions may form either by deliquescence of salt or dust accumulated during the dry periods or by dripping from the emplacement walls [2].

Alloy 22 or N06022 is nickel-based (Ni) and contains by weight $22 \%$ chromium $(\mathrm{Cr}), 13 \%$ molybdenum (Mo), $3 \%$ tungsten (W) and approximately $3 \%$ iron ( $\mathrm{Fe}$ ) [3]. Alloy 22 is highly resistant to general corrosion and pitting corrosion but may be susceptible to crevice corrosion under certain laboratory testing conditions [4-12]. The susceptibility of Alloy 22 to crevice corrosion depends strongly on the composition of the electrolyte solution, temperature, and applied potential. In general, the environment becomes more aggressive with increases in chloride concentration, temperature, and applied potential [12]. Chloride is a promoter of crevice corrosion while nitrate is an inhibitor [12].

The aim of this paper is to show that even though crevice corrosion may be initiated in Alloy 22, it does not propagate at a constant penetration rate. Constant potential tests were carried out in several concentrated electrolyte solutions containing chloride and nitrate. These experiments were originally undertaken to test the validity of the use of the repassivation potential for use as a critical potential for crevice corrosion initiation [9]. However, the reported tests are also used in this paper to calculate stifling rate parameters.

\section{Review of Crevice Corrosion Initiation and Propagation}

Austenitic alloys such as Alloy 22 (N06022) that rely on the stability of a thin chromium oxide $\left(\mathrm{Cr}_{2} \mathrm{O}_{3}\right)$ film for protection against corrosion are prone to crevice corrosion, a form of localized corrosion. Crevice corrosion occurs within shielded or occluded regions on a metal surface and requires the presence of a continuous liquid film connecting the occluded region to the external bulk material. In the Yucca Mountain emplacement, occluded regions could be formed at the waste package pallet interfaces or under mineral deposits on the waste package surface (contact crevices). Within this region, a volume of stagnant liquid must form in order for crevice corrosion to occur. The crevice geometry must be wide enough to permit liquid entry but narrow enough to maintain the stagnant layer. In a natural setting, crevice corrosion initiation involves: 1) local depletion of oxygen in the crevice; 2) spatial separation of the anode, where electrons are produced (the crevice), from the cathode, where electrons are consumed (the bulk surface); 3) metal dissolution within the crevice; and 4) hydrolysis of dissolved metal ions and the accompanying acidification of the creviced region [13]. Metal ion hydrolysis also leads to a charge imbalance within the crevice and migration of anions such a chloride into the creviced region. The crevice grows by anodic processes (metal dissolution) within the crevice balanced 
by cathodic reduction on the bulk surfaces and, to a lesser extent, by reduction of $\mathrm{H}^{+}$within the crevice [13].

A number of characteristics of crevice corrosion will tend to deplete the limited supply of water available in the brine formed by dust deliquescence. Hydrolysis of dissolved metal ions (Equation 1) consumes water through reactions of the form

$$
\mathrm{M}^{x+}+y \mathrm{H}_{2} \mathrm{O} \rightarrow \mathrm{M}(\mathrm{OH})_{y}^{(x-y)+}+y H^{+}
$$

Reactions at the cathode also consume water. The cathode and anode, although spatially separated, must have a continuous solution path between them (the deliquescent film or brine droplet) as well as a continuous electrical path (the alloy itself). In order for growth to continue, the solution must maintain contact with the crevice tip (the site of metal ion dissolution). As the crevice grows, more solution volume is required to fill the new volume of crevice not occupied by corrosion products. As noted, water in the solution is being consumed at the anode and the cathode, so this water must be replaced by condensation from the gas phase or additional seepage for the corrosion process to continue.

Progress of crevice or localized corrosion requires precipitation of solid phases in the cathodic region, which for fine crevices (e.g., contact crevices) would then impede the transport processes necessary for the corrosion cell to function. The required transport includes transport of ionic species and $\mathrm{O}_{2}$ in the aqueous phase, and transport of $\mathrm{H}_{2} \mathrm{O}$ and $\mathrm{O}_{2}$ through the gas phase to reach the aqueous phase. Any decrease of the cathodic area available to support the dissolution reaction (e.g., from solid precipitates) would lead to cathodic limitation of the crevice corrosion process. Any blockage of the gas-phase pathway for replenishment of reactants would similarly impede corrosion progress.

Above the critical crevice temperature, the effect of high temperatures on the mechanism of crevice corrosion also tends to impede the extent. At higher temperatures, the diffusion rate of oxygen increases, promoting homogenization of the oxygen concentration profile, thereby decreasing the possibility of crevice corrosion initiation and promoting more a general passive corrosion. Similarly, increased temperatures enhance the diffusion of all species in solution, thereby promoting uniform solution conditions, and decreasing the stability of crevice chemistry.

\section{Power Law for Propagation of Localized Corrosion}

For a number of alloy/exposure environment combinations, the rate of localized corrosion penetration has been observed to decrease with time [14-17]. A simple timedependent model used in the literature for this behavior is based on growth of hemispherical pits and yields a penetration law of the form

$$
D=k \cdot t^{n}
$$

where $\mathrm{D}$ is the depth of penetration, $\mathrm{t}$ is time, and $\mathrm{k}$ is a growth constant. The growth constant depends on the properties of the material, particularly its susceptibility to anodic dissolution in the acidic environment prevailing at a propagating site of localized corrosion. The time exponent, $\mathrm{n}$, would be about 0.5 for both diffusion-controlled (i.e., diffusion of metal ions out of the pit) and ohmically controlled (i.e., rate determined by the ohmic potential drop which develops in the electrolyte in the pit) pit growth $[15,18]$. This growth law is followed in the pitting and crevice corrosion of stainless steels $[14,17]$ and was used in a separate analysis of Alloy 22 by EPRI [19]. A key point of this growth law is that the rate of penetration is proportional to $t^{n-1}$ meaning that the rate of penetration decreases with increasing time, particularly over repository time scales. This behavior is schematically illustrated in Figure 1.

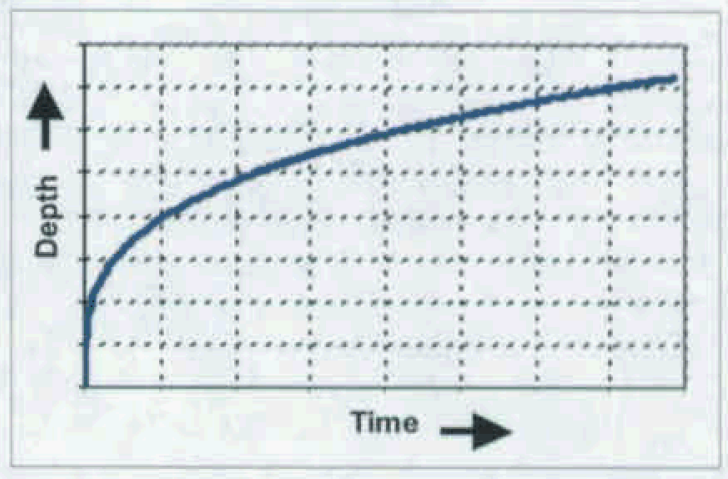

Figure 1. Schematic Plot of Depth vs. Time for Power Law Growth with Exponent Less than One

The literature data available for less corrosion-resistant materials (e.g., iron, copper, Titanium Grade 2) [14, 20-23] clearly show that a penetration growth law of the form of Equation 2 is appropriate, and that a value of $n=0.5$ is justifiable. A key point with the materials discussed above (e.g., iron, carbon steel, copper and Titanium Grade 2) is that they are materials that would be expected to undergo rapid propagation. Providing it is not stifled by the accumulation of corrosion product deposits or slow cathodic kinetics, propagation would be limited only by diffusive or ohmic effects, leading to a value of $n$ approaching 0.5. By contrast, for highly corrosion-resistant materials such as Alloy 22, which is designed to resist localized corrosion, additional metallurgical features such 
as the ability of molybdenum to decrease the pitting current densities $[16,24]$ could decrease $n$ well below 0.5 . Molybdenum reduces the active dissolution rate within the pit or crevice preventing the maintenance of the critical chemistry necessary to sustain propagation, leading to repassivation and a cessation of crevice growth. Kehler et al. [4] showed that the depth of crevice penetration for Alloy 22 in electrochemically driven studies (i.e., no possibility of cathodic limitation) using extremely saline (5 $\mathrm{M} \mathrm{LiCl}$ ) solutions at $85^{\circ} \mathrm{C}$ was limited to less than $0.1 \mathrm{~mm}$, well below the $20 \mathrm{~mm}$ waste package outer barrier wall thickness.

\section{Experimental}

Alloy 22 specimens were prepared from 1 -inch thick plate. There were several heats of material used in this research. The chemical composition of the most used specimens of Alloy 22 are given in Table 1. The specimens were prism crevice assemblies (PCA), which were fabricated based on the washer for crevice forming described in ASTM G 48 and G 78 [25] (Figure 2). The exposed surface area of the PCA specimen was $14.06 \mathrm{~cm}^{2}$. The total area covered by the erevice formers was approximately $1.5 \mathrm{~cm}^{2}$. All tested specimens were given a 600 grit surface finish and were degreased in acetone and treated ultrasonically for 5 minutes in de-ionized (DI) water 1 hour prior to testing. Specimens were used in the as-welded (ASW) condition. The weld was produced with matching filler metal using Gas Tungsten Arc Welding (GTAW). The welded specimens were not all weld metal but contained a weld seam, which varied in width from approximately 8 to 15 $\mathrm{mm}$. The weld seam extended across the two surfaces of the specimen that were purposely creviced with the multiple tooth washer (Figure 2).

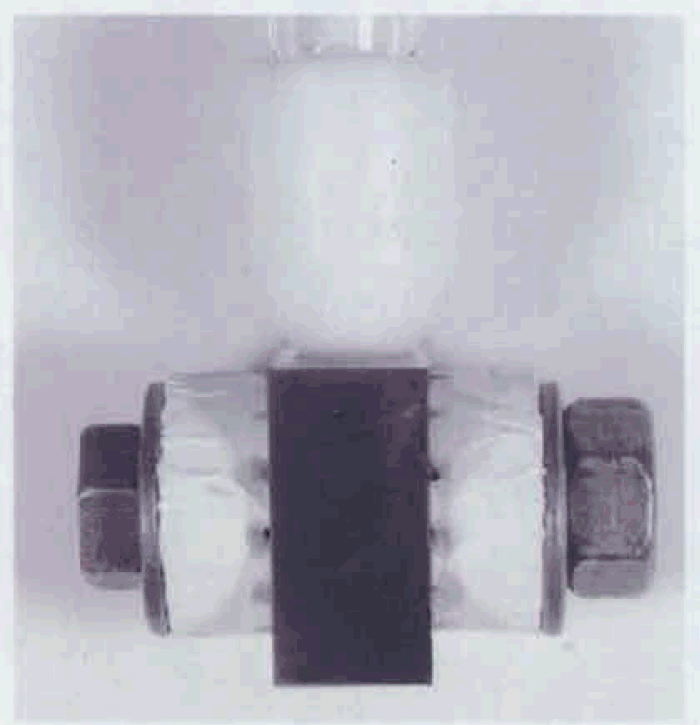

Figure 2. Creviced Alloy 22 Specimen (PCA)
Electrochemical tests were carried out in deaerated solutions given in Table II. The $\mathrm{pH}$ of the solutions was approximately 5-6. Nitrogen $\left(\mathrm{N}_{2}\right)$ was purged through the solution at a flow rate of $100 \mathrm{cc} / \mathrm{min}$ for 24 hours while the corrosion potential $\left(\mathrm{E}_{\text {corr }}\right)$ was monitored. Nitrogen bubbling was continued throughout all the electrochemical tests. The electrochemical tests were conducted in a oneliter, three-electrode, borosilicate glass flask (ASTM G 5) [25]. A water-cooled condenser combined with a water trap was used to avoid evaporation of the solution and to prevent the ingress of air (oxygen). The temperature of the solution was controlled by immersing the cell in a thermostatisized silicone oil bath. All the tests were carried out at ambient pressure. The reference electrode was saturated silver chloride (SSC) electrode, which at ambient temperature has a potential of $199 \mathrm{mV}$ more positive than the standard hydrogen electrode (SHE). The reference electrode was connected to the solution through a waterjacketed Luggin probe so that the electrode was maintained at near ambient temperature. The counter electrode was a flag $\left(36 \mathrm{~cm}^{2}\right)$ of platinum foil spot-welded to a platinum wire. All the potentials in this paper are reported in the $\mathrm{SSC}$ scale.

Basically the test sequence for each specimen consisted of three parts: (1) Ecorr evolution as a function of time for 24 hrs, (2) Polarization Resistance (ASTM G 59) three measurements and (3) A constant potential (Table II) was applied for nominally one week while the current was monitored. More details of the specimens and testing characteristics are found elsewhere [26]. After the tests, the specimens were examined using both optical and scanning electron microscopy.

\section{Results}

Figure 3 shows a plot of the current vs. time data for the tests listed in Table II. After crevice corrosion initiates, the current increases to a maximum and then decreases to passive levels with increasing exposure time indicating that crevice corrosion has stifled. In most tests, the net current eventually decreased to negative values indicating that the cathodic current was higher than the anodic current and suggesting that the cathodic reduction of protons and/or nitrate inside the crevice was more important that the dissolution of the metal. Table II shows that crevice corrosion initiated in most of the specimens, but that the amount of charge circulated in each specimen was different depending on the electrolyte where the tests were performed and the applied potential (Table II). For example, for the same applied potential, electrolytes solutions with a higher nitrate to chloride ratio develop smaller crevice corrosion sites than electrolytes with a lower nitrate to chloride ratio [26]. 


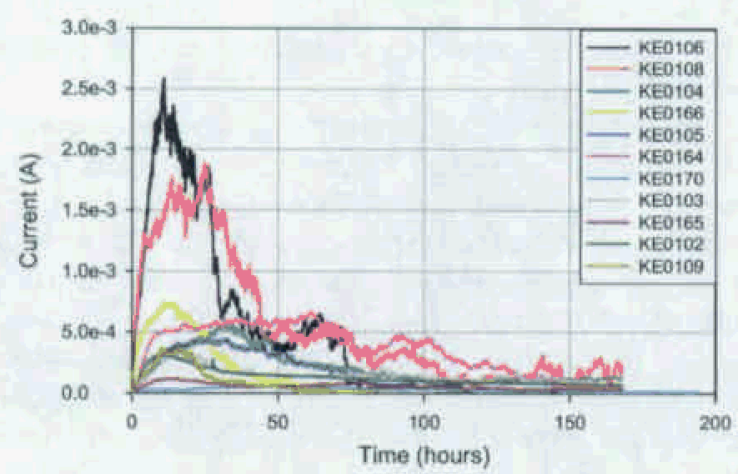

Figure 3. Constant Potential Tests of Creviced Alloy 22 Specimens (PCA)

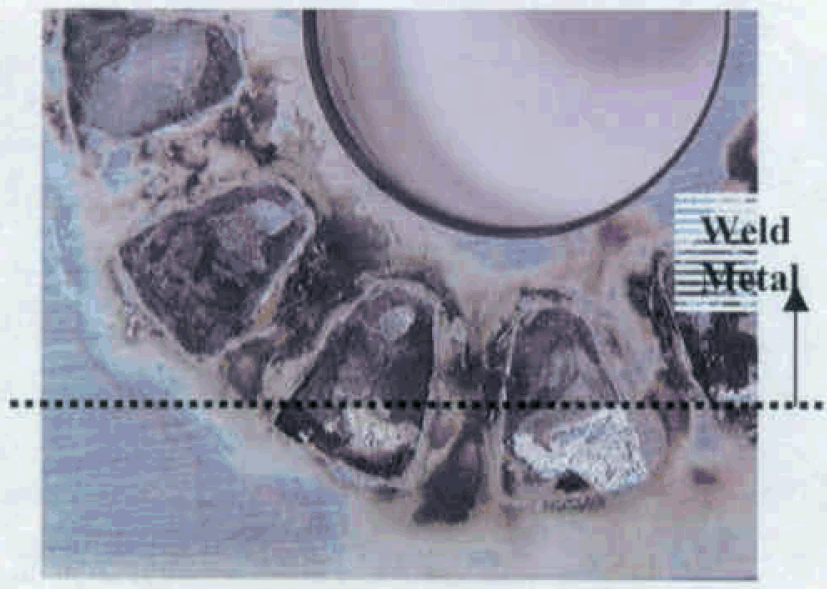

Figure 4. Appearance of Specimen KE0164 after the test Magnification X 20
Figure 4 shows the typical appearance of the crevice corrosion attack, which progressed under the serrated crevice formers. The attack propagated both in the weld seam and in the base metal. In Figure 4, the whiter regions of the crevice formers at the 5,6 and 7 o'clock positions correspond to base metal. The upper (darker) regions correspond to weld metal. The crevice corrosion attack is crystallographic in the base metal and interdendritic in the weld seam, suggesting the formation of hydrochloric acid in the crevice during the attack [26].

In general, the data in Figure 3 are not suitable for detailed quantitative analysis (i.e., unequivocal evaluation of parameters for use in the power law) because:

1. There are 24 potential locations ( 24 crevices) where crevice corrosion can initiate during the exposure time. Each crevice may initiate crevice corrosion at different times during the exposure (or not initiate crevice corrosion during the exposure). If crevice corrosion initiated at one location, then stifled just as another location initiated crevice corrosion, quantitative interpretation of the data is difficult. Data collected from a sample with only one creviced region could alleviate this issue.

2. The general corrosion rate (which corresponds to the passive current density) decreases with time. Therefore, the passive current density value to which the curves should decay after stifling decreases with time. Also, the cathodic current density capable of being generated on a more perfectly formed and less defective (i.e., older) passive film would be less than that capable of being generated on a more defective (i.e., younger) passive film. Data from samples exposed to the environment for longer periods of time before potential is applied could alleviate this issue.

Table I. Chemical Composition of the Tested Alloy 22 Specimens

\begin{tabular}{|c|c|c|c|c|c|c|}
\hline Element & $\mathrm{Ni}$ & $\mathrm{Cr}$ & $\mathrm{Mo}$ & $\mathrm{W}$ & $\mathrm{Fe}$ & Others \\
\hline $\begin{array}{c}\text { Nominal ASTM B 575 } \\
\text { PCA Specimen Number and } \\
\text { Heat }\end{array}$ & $50-62$ & $20-22.5$ & $\begin{array}{c}12.5- \\
14.5\end{array}$ & $2.5-3.5$ & $2-6$ & $\begin{array}{c}2.5 \mathrm{Co}-0.5 \mathrm{Mn}-0.35 \mathrm{~V} \\
\text { max. }\end{array}$ \\
\hline $\begin{array}{c}\text { KE0101-0150 Base } \\
\text { Heat 059902LL2 }\end{array}$ & 59.56 & 20.38 & 13.82 & 2.64 & 2.85 & $0.16 \mathrm{Mn}-0.17 \mathrm{~V}$ \\
\hline $\begin{array}{c}\text { KE0101-0150 Weld Wire } \\
\text { Heat XX2048BG }\end{array}$ & 59.4 & 20.48 & 14.21 & 3.02 & 2.53 & $0.2 \mathrm{Mn}$ \\
\hline $\begin{array}{c}\text { KE0151-0239 Base } \\
\text { Heat 2277-0-3183 }\end{array}$ & 55.29 & 21.23 & 13.37 & 2.93 & 3.65 & $1.7 \mathrm{Co}-0.23 \mathrm{Mn}-$ \\
\hline $\begin{array}{c}\text { KE0151-0239 Weld Wire } \\
\text { Heat XX1829BG }\end{array}$ & 59.31 & 20.44 & 14.16 & 3.07 & 2.2 & $0.21 \mathrm{Mn}-0.15 \mathrm{Cu}$ \\
\hline
\end{tabular}


Table II. Summary of Data from Constant Potential Experiments

\begin{tabular}{|c|c|c|c|c|c|c|c|}
\hline $\begin{array}{l}\text { Specimen } \\
\text { Identity }\end{array}$ & $\mathbf{T}\left({ }^{\circ} \mathrm{C}\right)$ & Solution Composition & $\mathrm{NO}_{3} / \mathrm{Cl}$ & $\begin{array}{c}\text { Applied } \\
\text { Potential } \\
\text { (mV SSC) }\end{array}$ & $\begin{array}{c}\text { Duration } \\
\text { (hour) }\end{array}$ & \begin{tabular}{|c|} 
Crevice \\
Corrosion \\
$(\mathrm{Y} / \mathrm{N})$
\end{tabular} & Stifling? $(\mathbf{Y} / \mathbf{N})$ \\
\hline KE0106 & 100 & $3.5 \mathrm{~m} \mathrm{NaCl}+0.175 \mathrm{~m} \mathrm{KNO}_{3}$ & 0.05 & 100 & $168^{\mathrm{a}}$ & $\mathrm{Y}$ & $\bar{Y}$ \\
\hline KE0108 & 100 & $3.5 \mathrm{~m} \mathrm{NaCl}+0.175 \mathrm{~m} \mathrm{KNO}_{3}$ & 0.05 & 100 & 168 & $\bar{Y}$ & $\bar{Y}$ \\
\hline KE0104 & 100 & $3.5 \mathrm{~m} \mathrm{NaCl}+0.525 \mathrm{~m} \mathrm{KNO}_{3}$ & 0.15 & 100 & 168 & $\bar{Y}$ & $\bar{Y}$ \\
\hline KE0166 & 100 & $3.5 \mathrm{~m} \mathrm{NaCl}+0.525 \mathrm{~m} \mathrm{KNO}_{3}$ & 0.15 & 100 & $194^{6}$ & $\mathrm{Y}$ & $\mathrm{Y}$ \\
\hline KE0105 & 100 & $6 \mathrm{~m} \mathrm{NaCl}+0.3 \mathrm{~m} \mathrm{KNO}_{3}$ & 0.05 & 100 & 168 & $\bar{Y}$ & $\bar{Y}$ \\
\hline KE0164 & 100 & $6 \mathrm{~m} \mathrm{NaCl}+0.3 \mathrm{~m} \mathrm{KNO}_{3}$ & 0.05 & 0 & 168 & $\mathrm{Y}$ & $\mathrm{Y}$ \\
\hline KE0170 & 100 & $6 \mathrm{~m} \mathrm{NaCl}+0.9 \mathrm{~m} \mathrm{KNO}_{3}$ & 0.15 & 0 & 194 & $\bar{Y}$ & $\bar{Y}$ \\
\hline KE0103 & 100 & $6 \mathrm{~m} \mathrm{NaCl}+0.9 \mathrm{~m} \mathrm{KNO}{ }_{3}$ & 0.15 & 100 & 168 & $\mathrm{Y}$ & $\mathrm{Y}$ \\
\hline KE0165 & 100 & $6 \mathrm{~m} \mathrm{NaCl}+0.9 \mathrm{~m} \mathrm{KNO}_{3}$ & 0.15 & 0 & 168 & $\mathrm{Y}$ & $\bar{Y}$ \\
\hline KE0102 & 120 & $5 \mathrm{M} \mathrm{CaCl}_{2}+0.5 \mathrm{M}\left(\mathrm{CaNO}_{3}\right)_{2}$ & $\sim 0.1$ & 100 & 168 & $\bar{Y}$ & $\bar{Y}$ \\
\hline KE0109 & 155 & $18 \mathrm{~m} \mathrm{CaCl}_{2}+0.9 \mathrm{~m} \mathrm{Ca}\left(\mathrm{NO}_{3}\right)_{2}$ & 0.1 & 50 & $117^{\mathrm{c}}$ & $\mathrm{N}(\mathrm{LC})$ & $\bar{Y}$ \\
\hline \multicolumn{8}{|c|}{$\begin{array}{l}\text { Data for sample KE0106 up to } 79 \text { hours used. Subsequent current data had negative values. } \\
\text { Data for sample KE0166 up to } 119 \text { hours used. Subsequent current data had negative values. } \\
\text { c Data for sample KE0109 up to } 72 \text { hours used. Subsequent current data had negative values } \\
\text { LC = Localized Corrosion outside the Crevice Formers }\end{array}$} \\
\hline
\end{tabular}

\section{Analysis of the Constant Potential Data}

The data in Figure 3 was fit with a power law similar to Equation 1 (with an extra A constant relative to the power law), where $D$ is the depth of penetration, $t$ is time, $k$ is a growth constant, and $\mathrm{A}$ is a fitting constant. The primary intent of this exercise is to estimate $n$, the time exponent, which, as noted earlier, should be about 0.5 for both diffusion-controlled (i.e., diffusion of metal ions out of the pit) and ohmically controlled (i.e., rate determined by the ohmic potential drop which develops in the electrolyte in the pit) pit growth. While $\mathrm{A}$ does not have a physical interpretation in this context (i.e., the depth at time zero should be zero), its inclusion allows for better fitting of the time exponent. The reader should again take note of the reasons given above as to why the data are not suitable for detailed quantitative analysis (i.e., unequivocal evaluation of parameters for use in the power law).

The corrosion rate or dissolution rate of the alloy inside the crevices, $C R$ in $\mathrm{mm} / \mathrm{yr}$, can be calculated from the corrosion current density, $i_{\text {corr }}$, using Equation 3 (ASTM G 102) [25]

$$
C R=K_{1} \frac{i_{c o r r} \cdot E W}{\rho}
$$

where $\mathrm{K}_{1}=3.27 \times 10-3 \mathrm{~mm} \mathrm{~g} / \mu \mathrm{A} \mathrm{cm} \mathrm{yr}$, EW is the equivalent weight of Alloy 22 (23.28) [25] and $\rho$ is the density of Alloy $22\left(8.69 \mathrm{~g} / \mathrm{cm}^{3}\right.$ for N06022). The current density, $\mathrm{i}$, was obtained by dividing the current by the area of one creviced region (there were 24 creviced regions on each sample with a total area of $1.50 \mathrm{~cm}^{2}$ therefore the area of one creviced region is about $0.0625 \mathrm{~cm}^{2}$ ). This treatment is very conservative since it is likely that the measured current resulted from more than one creviced region (i.e., the actual corrosion rate was lower than is being estimated here). Figure 4 shows that most if not all creviced regions were attacked by crevice corrosion, that is, considering that all the current originated in only one creviced spot is highly conservative.

The corrosion rates obtained using Equation 3 were converted to $\mathrm{mm} / \mathrm{hr}$ by dividing by $8,766 \mathrm{hrs} / \mathrm{yr}$. The corrosion rates were then integrated over time through a simple sum of rectangles (sum over all time steps of length of time step multiplied by corrosion rate) to get profiles of depth, $D$, versus time, $t$. The length of each time step was the same as the length of the time steps used to report the measured current data. Plots of depth versus time for all specimens analyzed in this way are presented in Figure 5. Even using this conservative treatment, no calculated crevice depth exceeds $1.4 \mathrm{~mm}$ over the length of the experiment. 


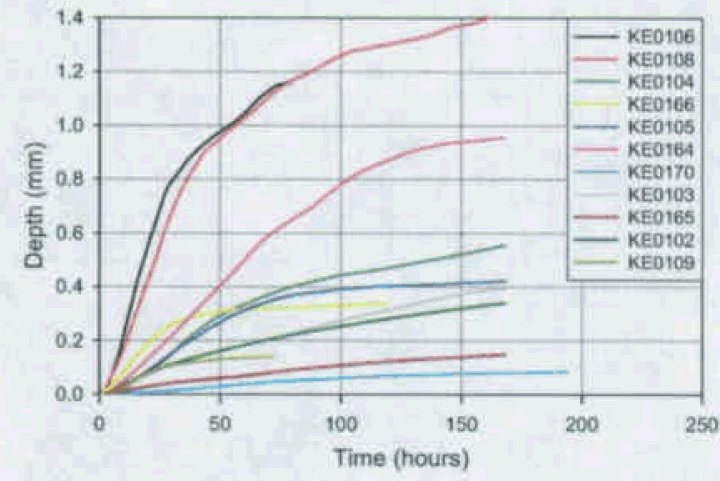

Figure 5. Calculated Depth of Crevice Corrosion Attack during Constant Potential Tests

Fitting these depth versus time profiles to the power law equation

$$
D=A+k t^{n}
$$

Equation 4 yields estimates for $\mathrm{A}, \mathrm{k}$, and $\mathrm{n}$ as shown in Table III. The $\mathrm{R}^{2}$ values obtained indicate that Equation 4 fits the data very well $\left(R^{2}\right.$ is close to 1$)$. The fitting parameter, $\mathrm{A}$, is always negative for this data set, indicating that, if this fit were to be used to estimate crevice depths, it would be conservative to ignore it. The growth constant, $k$, varies from about 0.005 to 0.758 and averages about 0.2 $\mathrm{mm} / \mathrm{hr}$. The time exponent, $\mathrm{n}$, varies from about 0.094 to 0.690 and averages about 0.439 . There are several caveats to direct application of these estimates, including: (1) As mentioned earlier, there are 24 potential locations (24 crevices) where crevice corrosion can initiate during the exposure time. Each crevice may initiate crevice corrosion at different times during the exposure (or not initiate crevice corrosion during the exposure). If crevice corrosion initiated at one location, then stifled just as another location initiated crevice corrosion, quantitative interpretation of the data is difficult. Data collected from a sample with only one creviced region could alleviate this issue. (2) The rates calculated are based on all current measured originating from just one of the creviced regions or about $1 / 225$ th of the total sample area or $1 / 24$ th of the total creviced area. (3) The general corrosion rate (which corresponds to the passive current density) decreases with time. Therefore, the passive current density value to which the curves should decay after stifling decreases with time. Also, the cathodic current density capable of being generated on a more perfectly formed and less defective (i.e., older) passive film would be less than that capable of being generated on a more defective (i.e., younger) passive film. Data from samples exposed to the environment for longer periods of time before potential is applied could address this issue.

Table III. Summary of Power Law Fitting

\begin{tabular}{|l|c|c|c|c|c|}
\hline \multicolumn{1}{|c|}{ Specimen } & $\begin{array}{c}\mathrm{mV} \mathrm{SSC} \\
\text { Applied }\end{array}$ & $\begin{array}{c}\mathbf{A} \\
\mathbf{m m}\end{array}$ & $\begin{array}{c}\mathbf{k} \\
\mathbf{m m} / \mathbf{h r}^{\prime \prime}\end{array}$ & $\mathbf{R}^{\mathbf{2}}$ \\
\hline KE0106 & 100 & -0.432 & 0.309 & 0.385 & 0.973 \\
\hline KE0108 & 100 & -0.983 & 0.758 & 0.231 & 0.967 \\
\hline KE0104 & 100 & -0.173 & 0.083 & 0.428 & 0.975 \\
\hline KE0166 & 100 & -0.760 & 0.718 & 0.094 & 0.911 \\
\hline KE0105 & 100 & -0.261 & 0.168 & 0.285 & 0.942 \\
\hline KE0164 & 0 & -0.181 & 0.061 & 0.588 & 0.981 \\
\hline KE0170 & -150 & -0.016 & 0.005 & 0.597 & 0.978 \\
\hline KE0103 & 100 & -0.030 & 0.013 & 0.690 & 0.999 \\
\hline KE0165 & 0 & -0.013 & 0.006 & 0.663 & 0.997 \\
\hline KE0102 & 100 & -0.048 & 0.027 & 0.523 & 0.998 \\
\hline KE0109 & 100 & -0.068 & 0.051 & 0.343 & 0.948 \\
\hline Averages & & -0.270 & 0.200 & 0.439 & 0.970 \\
\hline
\end{tabular}


(4) The results are highly conservative because corrosion is forced through use of a constant potential via a potentiostat. There is no cathodic limitation in these tests because the forcing potential overwhelms ohmic and mass transport limitations. In the repository environment, the reaction will be cathode-limited, which would likely enhance the stifling effect. Also, in the current tests the amount of solution to dissolve away any corrosion product was unlimited when in the actual repository the amount of water will be limited.

Because of these caveats, especially the final one, these rates are not applicable to the repository environment. Rather the data here serve to illustrate that stifling does occur, and that it significantly inhibits penetration of Alloy 22. With no stifling $(n=1)$, the value of $k$ represents the initial corrosion rate, averaging $0.2 \mathrm{~mm} / \mathrm{hr}$. This would result in penetration in 100 hours. However, because of stifling, penetration slows markedly $(n=$ 0.439 ) and the mean predicted penetration time is 4 years.

\section{Conclusions}

- Crevice corrosion can be initiated in artificially creviced specimens of Alloy 22 if a constant potential is applied between the repassivation potential and the breakdown potential

- The output net current as a function of time has three characteristic domains, (1) initiation, (2) crevice corrosion nucleation and growth and (3) crevice corrosion stifling or repassivation

- In all the tested conditions, crevice corrosion developed for a limited time before it died due to repassivation of the corroded area

- The current vs. time profile that measures the charge or dissolution of the specimen in the corroded area can be explained using a power relationship between the output current and the testing time

- The average exponent " $n$ " of the power law is 0.439 suggesting a continuous slowing down of the penetration due to a typical diffusion controlled mechanism

- Electrolytes solutions with a higher nitrate to chloride ratio develop smaller crevice corrosion sites than electrolytes with a lower nitrate to chloride ratio

\section{ACKNOWLEDGMENTS}

This work was partially performed under the auspices of the U. S. Department of Energy by the University of California Lawrence Livermore National Laboratory under contract W 7405 Eng 48. The work was supported by the Yucca Mountain Project, which is part of the DOE
Office of Civilian Radioactive Waste Management (OCRWM).

\section{DISCLAIMER}

This document was prepared as an account of work sponsored by an agency of the United States Government. Neither the United States Government nor the University of California nor any of their employees, makes any warranty, express or implied, or assumes any legal liability or responsibility for the accuracy, completeness, or usefulness of any information, apparatus, product, or process disclosed, or represents that its use would not infringe privately owned rights. Reference herein to any specific commercial product, process, or service by trade name, trademark, manufacturer, or otherwise, does not necessarily constitute or imply its endorsement, recommendation, or favoring by the United States Government or the University of California. The views and opinions of authors expressed herein do not necessarily state or reflect those of the United States Government or the University of California, and shall not be used for advertising or product endorsement purposes.

\section{References}

1. Yucca Mountain Science and Engineering Report, U. S. Department of Energy, Office of Civilian Radioactive Waste Management, DOE/RW-0539, Las Vegas, NV, May 2001

2. G. M. Gordon, Corrosion, 58, 811 (2002)

3. ASTM International, "Non Ferrous Alloys," Standard B575, Volume 02.04 (ASTM, 2002: West Conshohocken, PA)

4. B. A. Kehler, G. O. llevbare and J. R. Scully, Corrosion, 1042 (2001).

5. D. S. Dunn, G. A. Cragnolino, and N. Sridhar, in Scientific Basis for Nuclear Waste Management XXIV, Vol. 608, p 89 (Materials Research Society, 2000: Warrendale, PA)

6. G. A. Cragnolino, D. S. Dunn and Y.-M. Pan, in Scientific Basis for. Nuclear Waste Management XXV, Vol. 713, p 53 (Materials Research Society, 2002: Warrendale, PA)

7. V. Jain, D. Dunn, N. Sridhar and L. Yang, Corrosion/2003, Paper 03690 (NACE International, 2003: Houston, TX)

8. D. S. Dunn, L. Yang, Y. - M. Pan and G. A. Cragnolino, Corrosion/2003, Paper 03697 (NACE International, 2003: Houston, TX)

9. J. H. Lee, T. S. E. Summers and R. B. Rebak, Corrosion/2004, Paper 04692 (NACE International, 2004: Houston, TX). 
10. D. S. Dunn, G. A. Cragnolino, Y. M. Pan and L. T. Yang, Corrosion/2004,. Paper 04698 (NACE International, 2004: Houston, TX).

11. K. J. Evans, A. Yilmaz, S. D. Day, L. L. Wong, J. C. Estill and R. B. Rebak "Electrochemical Methods to Determine Crevice Corrosion Repassivation Potential of Alloy 22 in Chloride Solutions," JOM, January 2005 (TMS, 2005: Warrendale, PA)

12. R. B. Rebak, Paper 05610, Corrosion/2005 (NACE International, 2005: Houston, TX)

13. M. G. Fontana, Corrosion Engineering, 3rd Edition (McGraw-Hill: 1986, New York, NY)

14. F. Hunkeler and H. Boehni, "Pit Growth Measurements on Stainless Steels" in Passivity of Metals and Semiconductors, Proceedings of the Fifth International Symposium on Passivity, Bombannes, France, May 30-June 3, 1983, Froment, M.; ed. Pages 655-660 (Elsevier, 1983: New York, NY)

15. R. McGuire; J. Vlasity; J. Kessler; A. Long; S. Childs; B. Ross; F. Schwartz; D. Shoesmith; M. Kolar; M. Apted; W. Zhou; E. Sudicky; G. Smith; M. Kozak; P. Salter; R. Klos; A. Venter; M. Stenhouse; B. Watkins and R. Little, Alternative Approaches to Assessing the Performance and Suitability of Yucca Mountain for Spent Fuel Disposal (EPRI TR-108732. Palo Alto, California, 1998)

16. G. S. Frankel, "Pitting Corrosion of Metals, A Review of the Critical Factors." Journal of the Electrochemical Society, 145, (6), 2186-2198 (1998)

17. R. C. Newman and E. M. Franz, "Growth and Repassivation of Single Corrosion Pits in Stainless Steel." Corrosion, 40, (7), 325-330 (1984)

18. K. J. Vetter and H. H. Strehblow, "Pitting Corrosion in an Early Stage and its Theoretical Implications." Localized Corrosion, U.R. Evans Conference on Localized Corrosion, December 6-10, 1971, Williamsburg, Virginia, International Corrosion Conference Series, NACE-3, Pages 240-251. Houston, Texas: National Association of Corrosion Engineers, 1974: Houston TX)

19. EPRI (Electric Power Research Institute), Evaluation of the Proposed High-Level Radioactive Waste Repository at Yucca Mountain Using Total System Performance Assessment, Phase 6, EPRI TR1003031 (Electric Power Research Institute, 2002: Palo Alto, CA)

20. G. P. Marsh; K. J. Taylor and A. H. Harker 1991. The Kinetics of Pitting Corrosion of Carbon Steel Applied to Evaluating Containers for Nuclear Waste Disposal, SKB TR-91-62 (Stockholm, Sweden: Svensk Kärnbränsleförsörjning AB, 1991)

21. S. F. Mughabghab and T. M. Sullivan, "Evaluation of the Pitting Corrosion of Carbon Steels and Other Ferrous Metals in Soil Systems" Waste Management, 9, (4), 239-251 (1989)
22. S. M. Sharland; C. C. Naish; K. J. Taylor and G. P. Marsh, "An Experimental and Modelling Study of the Localized Corrosion of Carbon Steel Overpacks for the Geological Disposal of Radioactive Waste." Life Prediction of Corrodible Structures, Parkins, R.N., ed. Volume 1, Pages 402-418 (NACE International 1991: Houston, Texas)

23. H. Ishikawa, A. Honda and N. Sasaki, "Long Life Prediction of Carbon Steel Overpacks for Geological Isolation of High-Level Radioactive Waste." Life Prediction of Corrodible Structures," Parkins, R.N., ed. Volume 1, Pages 454-483 (NACE International 1994: Houston, Texas)

24. R. C. Newman, "The Dissolution and Passivation Kinetics of Stainless : Alloys Containing Molybdenum-I. Coulometric Studies of $\mathrm{Fe}-\mathrm{Cr}$ and Fe-Cr-Mo Alloys." Corrosion Science, 25, (5), 331 339 (1985)

25. ASTM International, Volume 03.02, Standards G 5, G 15, G 48, G 59, G 61, G 102 (ASTM International, 2003: West Conshohocken, PA)

26. A. Yilmaz, P. Pasupathi and R. B. Rebak, Paper PVP2005-71174, ASME Pressure Vessels and Piping Conference, 17-21 July 2005, Denver, CO (American Society of Mechanical Engineers, 2005: New York, NY). 